\title{
Spatial-Temporal Variations of Water Quality and Its Relationship to Land Use and Land Cover in Beijing, China
}

\author{
Xiang Chen ${ }^{1,2}$, Weiqi Zhou ${ }^{1,2, *}$, Steward T. A. Pickett ${ }^{3}$, Weifeng $\mathrm{Li}^{1}$ and Lijian Han ${ }^{1}$ \\ 1 State Key laboratory for Urban and Regional Ecology, Research Center for Eco-Environmental Sciences, \\ Chinese Academy of Sciences, No.18 Shuangqing Rd., Haidian District, Beijing 100085, China; \\ xiang8234@126.com (X.C.); li.wf@rcees.ac.cn (W.L.); ljhan@rcees.ac.cn (L.H.) \\ 2 University of Chinese Academy of Sciences, No.19A Yuquan Rd., Beijing 100049, China \\ 3 Cary Institute of Ecosystem Studies, Box AB, 2801 Sharon Turnpike, Millbrook, NY 12545, USA; \\ picketts@caryinstitute.org \\ * Correspondence: wzhou@rcees.ac.cn; Tel.: +86-10-6284-9268; Fax: +86-10-6291-5732
}

Academic Editor: Yu-Pin Lin

Received: 5 April 2016; Accepted: 25 April 2016; Published: 27 April 2016

\begin{abstract}
Rapid urbanization with intense land use and land cover (LULC) change and explosive population growth has a great impact on water quality. The relationship between LULC characteristics and water quality provides important information for non-point sources (NPS) pollution management. In this study, we first quantified the spatial-temporal patterns of five water quality variables in four watersheds with different levels of urbanization in Beijing, China. We then examined the effects of LULC on water quality across different scales, using Pearson correlation analysis, redundancy analysis, and multiple regressions. The results showed that water quality was improved over the sampled years but with no significant difference $(p>0.05)$. However, water quality was significantly different among nonurban and both exurban and urban sites $(p<0.05)$. Forest land was positively correlated with water quality and affected water quality significantly $(p<0.05)$ within a $200 \mathrm{~m}$ buffer zone. Impervious surfaces, water, and crop land were negatively correlated with water quality. Crop land and impervious surfaces, however, affected water quality significantly $(p<0.05)$ for buffer sizes greater than $800 \mathrm{~m}$. Grass land had different effects on water quality with the scales. The results provide important insights into the relationship between LULC and water quality, and thus for controlling NPS pollution in urban areas.
\end{abstract}

Keywords: water quality; land use and land cover; non-point source pollution; scale; Beijing

\section{Introduction}

Urbanization constitutes high concentrations of urban populations and is an important component of dramatic land transformation [1-3]. The changes have great impacts on stream ecosystems, such as the degradation of water quality, simplification of the channel, and decline of biodiversity [4-6]. In general, water quality degradation is commonly caused by both non-point sources (NPS) of runoff pollution and point sources (PS) of wastewater discharge. However, with the development of a city and the improvement of wastewater treatment, PS pollution is significantly reduced, and NPS pollution from surface runoff is now becoming a problem for urban water quality [7]. Meanwhile, because human activities differ in intensity in different areas, water quality degradation might be spatially heterogeneous [8,9]. This is particularly perceptible in catchments with environmental land use conflicts $[10,11]$. Therefore, it is important to analyze the characteristics of river riparian land use/land cover (LULC) and their influence on water quality for NPS pollution management. 
There are many studies about the impact of land use/cover on the water quality $[7,12-16]$. However, the previous studies mainly concentrated on the impacts of the main LULC types of exurban and urban on water quality. In exurban or rural areas, crop and forest land are the primary LULC types; they can increase Nitrogen, Phosphorous, and pesticide concentrations in nearby river water through agricultural activities [17-22]. In urban areas, the main LULC type is impervious surfaces. They impact on water quality through higher pollutant concentrations and by increasing the composition of particles, nutrients and metals in runoff waters [23-26]. Other LULC types, such as water and turf grass, however, have received relatively little attention in research on water quality, although they can also have important effects on water quality. For example, previous studies have shown that percentage cover of water within a catchment had a positive effect on the water quality in a river due to dilution and degradation of pollutants [7]. Grass cover, however, may have a more complex relationship with water quality [19]. The increase of grass coverage was found to increase the concentrations of water pollutants in some case studies [7], but to reduce water pollutants in others [27]. In order to understand the water quality over spatial heterogeneity in large areas, the LULC types which can impact water quality should be analyzed.

The problem of how LULC types influence water quality is very important for water research and management. However, there is controversy regarding to what extent LULC impacts on water quality. Controversy may emerge from the combination of cover class with spatial configuration of the cover. The width of buffer zone beside streams is one case of LULC complexity. For example, $6 \mathrm{~m}$ buffer zones composed of trees, shrubs, and grass could reduce total suspended solids by $94 \%$, total nitrogen by $78 \%$ and total phosphorus by $81 \%$ in runoff from agriculture [28]. Sweeney and Newbold [29] reviewed the literature and found that streamside forest buffer no less than $30 \mathrm{~m}$ wide were needed to protect the water quality, aquatic organisms and their habitat in small streams. Houlahan and Findlay [30], however, found that the buffer zone often needs to be nearly $4000 \mathrm{~m}$ at the watershed scale to protect the river water quality and the integrity of the aquatic ecological system.

Due to the geographical position and its rapid urbanization, Beijing suffers from a severe lack of water resources and high levels of water pollution. Many cities and regions in the world face the same risks [31]. Therefore, in order to promote sustainable development of the city and enhance human wellbeing, the protection of the aquatic environment is very important. The main objectives of this work are to (1) assess the spatial and temporal pattern of water quality in Beijing; and (2) to investigate the relationships between different types of land and the water quality variables; and (3) to explore the effects of different sizes of buffer zones on the relationship between LULC types and water quality to provide a reliable scientific basis for river management.

\section{Materials and Methods}

\subsection{Study Area}

This research covers metropolitan Beijing, which is located in the northwest of the North China Plain, adjoining the Inner Mongolian plateau to the north and Taihang Mountains to the west, and covers a total area of $16,410 \mathrm{~km}^{2}$. It is located in North Temperate Zone, with hot and rainy summers and cold and dry winters. The annual average temperature is about $12{ }^{\circ} \mathrm{C}$ and the annual mean precipitation is $588.1 \mathrm{~mm}$, with about $72 \%$ of the precipitation occurring in July and August with $<2 \%$ occurring in winter. As a politico-commercial and cultural center of China, the population of Beijing was estimated at 21.51 million and the gross domestic product (GDP) was 2133.08 billion RMB in 2014 [32]. Due to geographical contrasts and diverse functional orientations, the development of districts in Beijing is very heterogeneous (Figure 1). In the mountainous areas to the north and west of Beijing, the population density is very low. The degree of urbanization is high in the central plain which is the location of the main concentrations of population, industry and commerce. The northeast plain is far from the city center, and agriculture and subsidiary agricultural products are the main industry and the population is lower than in the central area. 




Figure 1. The spatial distribution of the 13 sample sites, overlapping on the topographic map of Beijing (from Google map, 20 July 2015).

\subsection{Sites Description and the Water Quality Data}

There are five river systems in Beijing. The Beiyun river originates from the local mountains, while the other four river systems, the Chaobai, Jiyun, Yongding, and Daqing, originate from other provinces. There has been no water in the Yongding or the Chaobai downstream since the construction of the Guanting and Miyun reservoirs, respectively. To represent different LULC of the watersheds in this study, 13 sites (S1-S13) are selected based on the established hydrologic monitoring stations (Figure 1). The sites were divided into nonurban, urban and exurban areas according to the watershed area location and the population density [3]. The population proportions of the nonurban, urban and exurban areas, respectively, are about 13:60:27. S1 is in the Juma river, which is a river of the Daqing river system, S2 is located at Yongding upstream, both of these sites are near the mountains and were considered as the nonurban areas. S3-S12 were located on the rivers of the Beiyun river system which has a total length of $89.4 \mathrm{~km}$ and an area of $4348 \mathrm{~km}^{2}$ in Beijing. The watershed is mainly located in the central urban area, and exhibits the greatest population aggregation. The Beiyun is also the main drainage system in Beijing [7]. S13 is in the Ju river, which is a tributary of the Jiyun river system. It is located in the Pinggu district, about $70 \mathrm{~km}$ away from the central city, where human activities are mainly industry, agriculture, and animal husbandry. It is an important source of agricultural and sideline products, and is considered as an exurban area.

Water quality data were obtained from the Beijing Municipal Environmental Monitoring Center, which takes monthly samples of surface water and uses standard methods from the Chinese State Environment Protection Bureau to analyze the water chemistry [33]. Five water quality variables 
were used because they had relatively complete data records for the study period and they represent important dimensions of water quality. The annual average of the following water quality variables was assessed: dissolved oxygen (DO), ammonium-nitrogen $\left(\mathrm{NH}_{3}-\mathrm{N}\right)$, chemical oxygen demand $\left(\mathrm{COD}_{\mathrm{Cr}}\right)$, permanganate index $\left(\mathrm{COD}_{\mathrm{Mn}}\right)$, and biochemical oxygen demand (BOD). Data of $\mathrm{NH}_{3}-\mathrm{N}, \mathrm{COD}_{\mathrm{Mn}}$, and BOD were from 2000 to 2010. Data of DO and COD $C r$ were from 2005 to 2010.

\subsection{Land Use and Land Cover (LULC) Data}

Land use and land cover data were obtained from classification of Landsat 5 Thematic Mapper (TM) images collected in 2000, 2005, and 2010, with a spatial resolution of $30 \mathrm{~m}$. These images obtained from United States Geological Survey (USGS), with the primary process though Level 1 Product Generation Survey (LPGS). In this pre-processing, systematic radiometric and geometric corrections were performed [34]. In order to improve the classification accuracy for the LULC map of 2005 and 2000, we further normalized the 2005 and 2000 TM image using 2010 TM data as the reference. Six LULC types were included, that is, impervious surface, crops, forest, grass, water, and barren. We combined an object-based classification approach with a backdating method for classifications. Specifically, classifications were first conducted on the images for 2010 using an object-based classification approach [35]. We then used the LULC data of 2010 as the reference, and applied a backdating approach to classify the images for 2000 and 2005 [36,37] (Figure 2). The overall accuracies of the classifications were $94 \%, 93 \%$ and $94 \%$ [38], respectively.

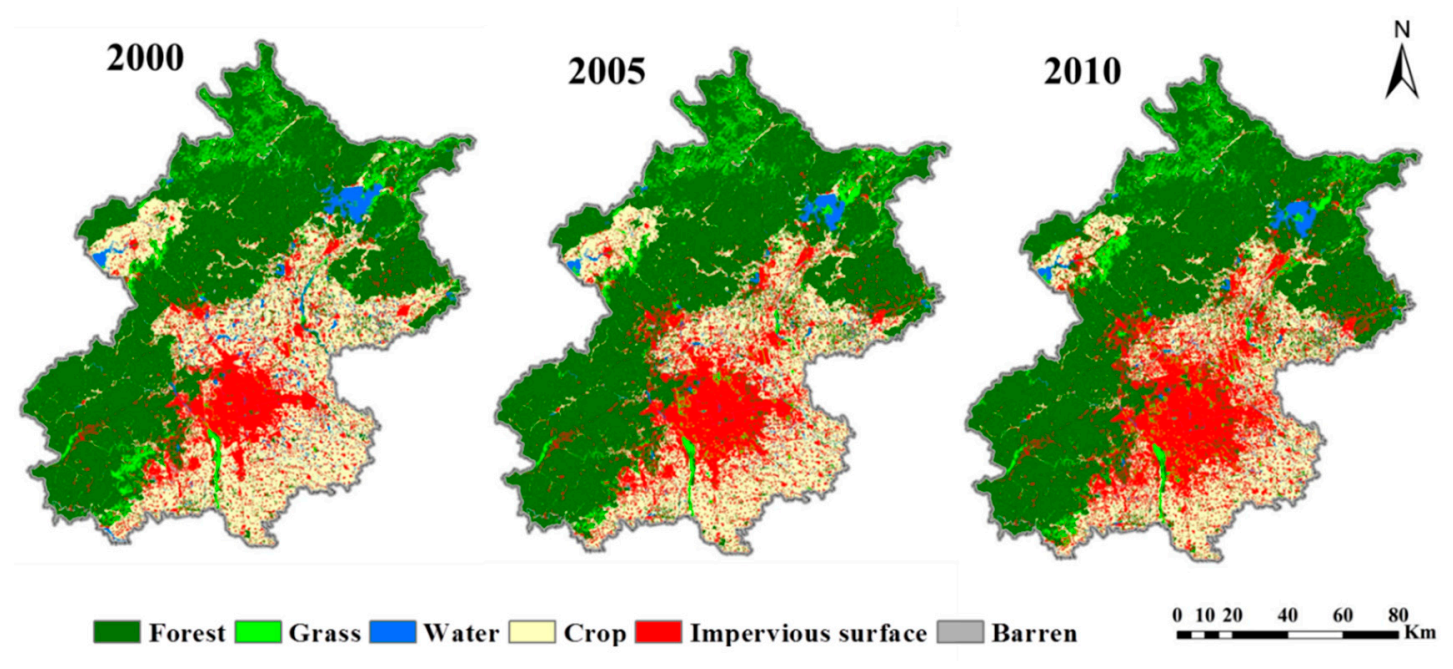

Figure 2. Land use and land cover of Beijing in 2000, 2005, and 2010.

\subsection{Construction Buffers in Urban Rivers}

We used contrasting buffer scales in this research, as previous studies have shown that the relationship between LULC and water quality was similar for the catchment scale and the scale of a $100 \mathrm{~m}$ buffer [12]. To quantify the effects the different LULC types might have on river water quality at different distances from the river, we reference another method used by researchers [39] and created a wide range of buffer zones $(100 \mathrm{~m}, 200 \mathrm{~m}, 300 \mathrm{~m}, 400 \mathrm{~m}, 500 \mathrm{~m}, 600 \mathrm{~m}, 800 \mathrm{~m}, 1000 \mathrm{~m}, 1200 \mathrm{~m}$, $1500 \mathrm{~m}$ and $2000 \mathrm{~m}$ ) for the sites using ArcGIS 10.1 (Environmental Systems Research Institute, Inc., Redlands, CA, USA). The urban stream syndrome showed that the interactions between streams and catchment are more complex in urban areas than natural systems because of the pipe drainage network [5]. To understand the relationship between water quality and land use in an urbanizing watershed, Sonoda et al. quantified percentages of different land use types within radius sizes of $30 \mathrm{~m}$, $90 \mathrm{~m}$ and $152 \mathrm{~m}$ at each site [24]. In this research, the length range of $1000 \mathrm{~m}$ upstream and $100 \mathrm{~m}$ downstream of each site was identified based on the first grade of classifying water source reserves in 
rivers [40], and the LULC types in buffers of the river section were used to calculate the relationship with water quality variables.

\subsection{Statistical Analysis}

One-way analysis of variance (ANOVA) was used to test the significance of the differences among the water quality variables from the three areas. Paired $t$-test was performed to test for significant differences of the $\mathrm{DO}$ and $\mathrm{COD}_{\mathrm{Cr}}$ between 2005 and 2010. Pearson correlation analysis was used to investigate the quantitative relationship between the LULC types and water quality variables in buffer zones at spatial scales in 2000, 2005, and 2010 (Figure 3). Redundancy analysis (RDA) was employed to identify the LULC types and patterns that impact the water quality variables across a series of spatial scales at different sites [41]. Before using the RDA, detrended correspondence analysis (DCA) was used to explore the length of the gradient of the four ordination axes before selecting the appropriate model in CANOCO 4.5 (Microcomputer Power, Ithaca, NY, USA). The longest gradient of the four ordination axes was less than 3 in all buffer zones, and the linear model of RDA was selected. From spatial and temporal scales, multiple regression analysis was used to test the correlations of LULC types within buffers and water quality in 2000, 2005, and 2010. In the analysis, water quality variables were treated as dependent variables and the percentage cover of LULC types were considered as independent variables. We used a conventional $5 \%$ level of significance to test the statistical significant difference in all statistical analyses with SPSS 19.0 (IBM, New York, NY, USA) for Windows. DCA and RDA were performed to use CANOCO 4.5 for Windows [41].



Figure 3. Framework of the methods used for analysis the relationships of LULC and water quality.

\section{Results}

\subsection{Spatial and Temporal Pattern of Water Quality}

The results showed that water quality in the study area had significant spatial variation. Water quality in nonurban area was better than the exurban and urban areas, and the exurban water quality was the worst. Concentrations of water quality variables were significantly higher $(p<0.01)$ in the exurban area than in the urban area except for $\mathrm{NH}_{3}-\mathrm{N}$, and in both areas water quality variables were significantly different $(p<0.001)$ from nonurban areas (Figure 4$)$. For example, the mean concentration of BOD in the exurban area was $115.8 \mathrm{mg} / \mathrm{L}$, higher than the $37.1 \mathrm{mg} / \mathrm{L}$ in the urban area and the mean of $2.22 \mathrm{mg} / \mathrm{L}$ in the nonurban area. The concentration of $\mathrm{COD}_{\mathrm{Cr}}$ in the exurban area was $220 \mathrm{mg} / \mathrm{L}$, also higher than $62.4 \mathrm{mg} / \mathrm{L}$ in the urban area and $14.1 \mathrm{mg} / \mathrm{L}$ in the nonurban area. However, the concentration of DO in nonurban area was $9.77 \mathrm{mg} / \mathrm{L}$, higher than $5.24 \mathrm{mg} / \mathrm{L}$ in the urban area and $2.92 \mathrm{mg} / \mathrm{L}$ in the exurban area. 




Figure 4. Spatial patterns of water quality in Beijing. The bars were the annual average concentrations for each station. "NonU" means nonurban sites; "ExU" means exurban sites.

During the period of 2000-2010, water quality improved in Beijing, especially from 2005 to 2010 (Table 1). In urban areas, for example, the concentration of $\mathrm{COD}_{\mathrm{Mn}}$ decreased from $22.89 \mathrm{mg} / \mathrm{L}$ in 2000, to $18 \mathrm{mg} / \mathrm{L}$ in 2005, and to $11.72 \mathrm{mg} / \mathrm{L}$ in $2010(p<0.01)$. BOD decreased from $58.82 \mathrm{mg} / \mathrm{L}$ in 2000, to $34.01 \mathrm{mg} / \mathrm{L}$ in $2005(p<0.05)$, and to $22.39 \mathrm{mg} / \mathrm{L}$ in $2010(p<0.01)$. Concentration of $\mathrm{NH}_{3}-\mathrm{N}$ and $\mathrm{COD}_{\mathrm{Cr}}$ also decreased in urban areas, but the concentration of DO increased from $4.87 \mathrm{mg} / \mathrm{L}$ in 2005 to $5.16 \mathrm{mg} / \mathrm{L}$ in 2010 ( $p>0.05)$. In exurban areas, the concentration of $\mathrm{NH}_{3}-\mathrm{N}, \mathrm{COD}_{\mathrm{Cr}}$, and $\mathrm{COD}_{\mathrm{Mn}}$ decreased from 2005 to 2010, and the concentration of DO increased from 2005 to 2010, however, the concentration of BOD increased from 2000 to 2010. In nonurban areas, the concentration of $\mathrm{NH}_{3}-\mathrm{N}$,

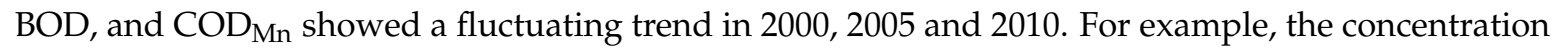
of BOD decreased from $2.25 \mathrm{mg} / \mathrm{L}$ in 2000 to $1.9 \mathrm{mg} / \mathrm{L}$ in 2005, but increased to $2.35 \mathrm{mg} / \mathrm{L}$ in 2010, which was higher than 2000. $\mathrm{COD}_{\mathrm{Mn}}$, however, the concentration increased from $1.95 \mathrm{mg} / \mathrm{L}$ in 2000 to $3.15 \mathrm{mg} / \mathrm{L}$ in 2005, but declined to $2.93 \mathrm{mg} / \mathrm{L}$ in 2010 .

Table 1. Mean value of water quality variables at nonurban areas, and urban areas and exurban areas in 2000, 2005, and 2010.

\begin{tabular}{cccccccccc}
\hline \multirow{2}{*}{ Variables } & \multicolumn{3}{c}{ Nonurban Area } & \multicolumn{3}{c}{ Urban Area } & \multicolumn{3}{c}{ Exurban Area } \\
\cline { 2 - 10 } & $\mathbf{2 0 0 0}$ & $\mathbf{2 0 0 5}$ & $\mathbf{2 0 1 0}$ & $\mathbf{2 0 0 0}$ & $\mathbf{2 0 0 5}$ & $\mathbf{2 0 1 0}$ & $\mathbf{2 0 0 0}$ & $\mathbf{2 0 0 5}$ & $\mathbf{2 0 1 0}$ \\
\hline $\mathrm{DO}$ & & 9.89 & 8.69 & & 4.87 & 5.16 & & 2.09 & 2.62 \\
$\mathrm{NH}_{3}-\mathrm{N}$ & 0.13 & 0.24 & 0.24 & 19.38 & 16.66 & 12.25 & 9.7 & 29.3 & 16.6 \\
$\mathrm{BOD}$ & 2.25 & 1.9 & 2.35 & 58.82 & 34.01 & 22.39 & 29.7 & 81.8 & 99.7 \\
$\mathrm{COD}_{\mathrm{Cr}}$ & & 17.35 & 12.6 & & 70.11 & 63.55 & & 229 & 174 \\
$\mathrm{COD}_{\mathrm{Mn}}$ & 1.95 & 3.15 & 2.93 & 22.89 & 18 & 11.72 & 20 & 25.1 & 23.4 \\
\hline
\end{tabular}




\subsection{Spatial Patterns of LULC in Buffers}

The proportion of the LULC types changed with an increase in the buffer zones from $100 \mathrm{~m}$ to $2000 \mathrm{~m}$ (Figure 5). Within the nonurban areas, as the buffer zones increased, the percentage of forest land increased from $44 \%$ to $82 \%$ in S1 and from $76 \%$ to $87 \%$ in S2, and the percentage of crop land and impervious surface decreased accordingly. The sites of S4, S5, S6, S7, and S11 were in the central urban area, and the mean percentage of impervious surface was about 70\%. Especially in S5 and S6, the percentage of impervious surface was over $90 \%$ from $100 \mathrm{~m}$ to $2000 \mathrm{~m}$, and the percentage of impervious surface was over $80 \%$ in S11 from $100 \mathrm{~m}$ to $2000 \mathrm{~m}$. The sites of S3, S9, S10 and S12 were near the central urban area, and the percentage of impervious surface was lower than the central urban area sites. However, the percentage of impervious surface increased with the increase of buffer zone. For example, the percentage of impervious surface increased from $7 \%$ in $100 \mathrm{~m}$ to $19.5 \%$ in $2000 \mathrm{~m}$ in S12. Crop land was the main LULC type in the exurban area and the mean percentage of crop land was $70.2 \%$ from $100 \mathrm{~m}$ to $2000 \mathrm{~m}$ in S13. However, the percentage of crop land decreased from $72 \%$ in $100 \mathrm{~m}$ to $61 \%$ in $2000 \mathrm{~m}$, but the percentage of forest land and impervious surface increased accordingly. Percentage of grass land in the sampling sites was lower than other LULC types. For example, the percentage of grass land was $0.5 \%$ in $100 \mathrm{~m}$ and $2.4 \%$ in $2000 \mathrm{~m}$ in 58 .



Figure 5. LULC characteristics of the river section within the buffers of $100 \mathrm{~m}, 200 \mathrm{~m}, 300 \mathrm{~m}, 600 \mathrm{~m}$, $800 \mathrm{~m}$, and $2000 \mathrm{~m}$. "imp" means impervious surface. 


\subsection{Relationship between Water Quality and LULC in Buffers}

\subsubsection{Results of Pearson Relationship Analysis}

Calculation of the Pearson correlation coefficient showed that the LULC types have very different impacts on water quality (Figure 6). Forest land was positively correlated with water quality. Pearson results showed that the forest land was positively correlated with $\mathrm{DO}$, but negatively correlated with $\mathrm{NH}_{3}-\mathrm{N}, \mathrm{BOD}, \mathrm{COD}_{\mathrm{Cr}}$ and $\mathrm{COD}_{\mathrm{Mn}}$ from $100 \mathrm{~m}$ to $2000 \mathrm{~m}$. However, the LULC types of water, crop, and impervious surface were negatively correlated with water quality. The LULC types were negatively correlated with $\mathrm{DO}$, but positively correlated with $\mathrm{NH}_{3}-\mathrm{N}, \mathrm{BOD}, \mathrm{COD}_{\mathrm{Cr}}$ and $\mathrm{COD}_{\mathrm{Mn}}$ except for impervious surface, which was negatively correlated with $C_{C O}$ from $100 \mathrm{~m}$ to $2000 \mathrm{~m}$. Pearson results demonstrated that grass land has a different correlation with water quality when the width of the buffer zone changed. Grass land was positively correlated with $\mathrm{NH}_{3}-\mathrm{N}, \mathrm{BOD}$, and $\mathrm{COD}_{\mathrm{Cr}}$, but negatively correlated with DO from $100 \mathrm{~m}$ to $500 \mathrm{~m}$; however, it was negatively correlated with $\mathrm{NH}_{3}-\mathrm{N}, \mathrm{BOD}$, and $\mathrm{COD}_{\mathrm{Cr}}$ from $600 \mathrm{~m}$ to $2000 \mathrm{~m}$.

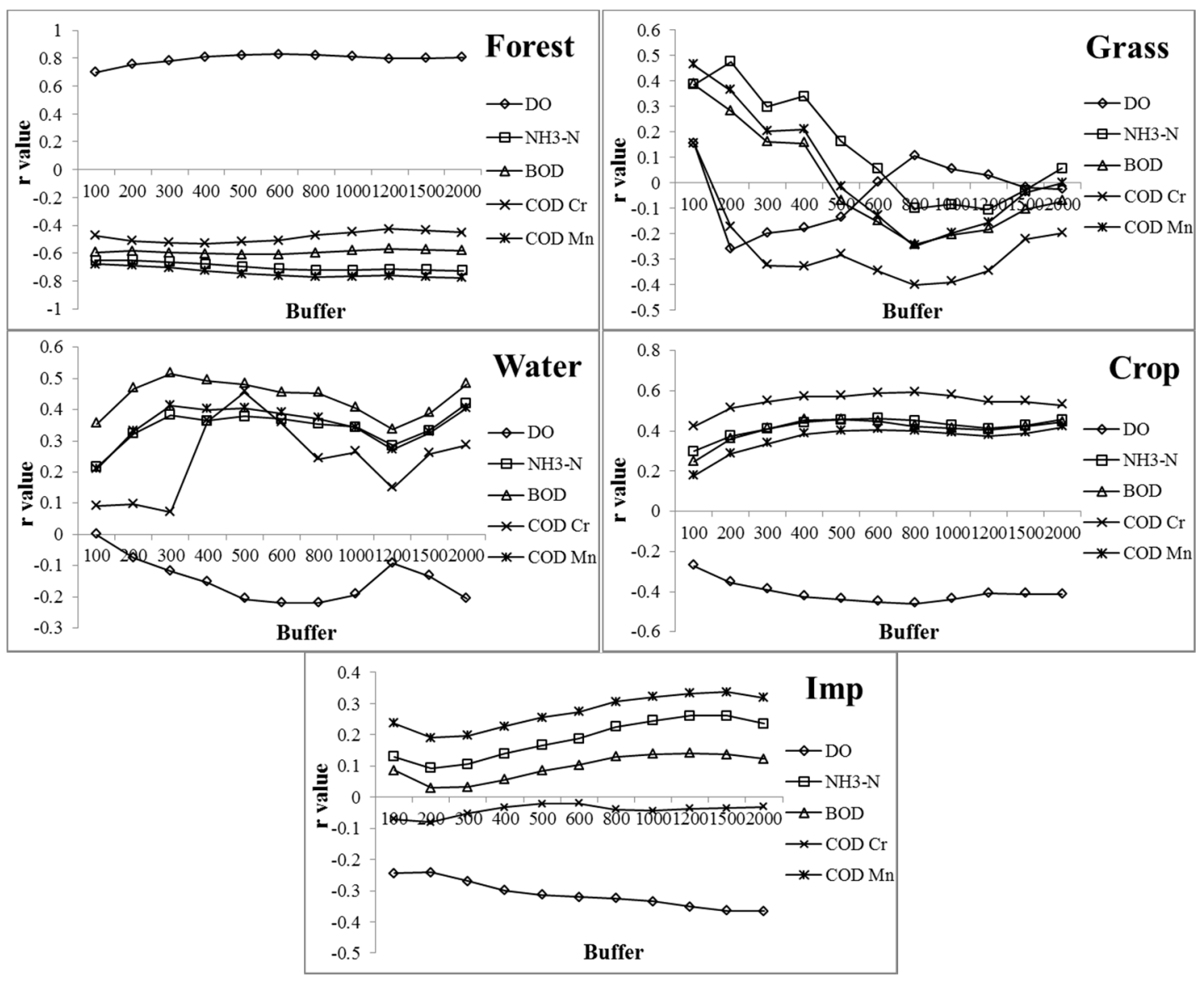

Figure 6. Pearson relationships between the LULC types of Forest, Grass, Water, Crop, and Imp (impervious surface) and water quality variables within the buffer of 100-2000 m.

Correlation coefficients between LULC types and water quality variables changed when the buffer zones increased. In the case of water, for example, the correlation coefficients with $\mathrm{COD}_{\mathrm{Cr}}$ were less than 0.1 in the first $300 \mathrm{~m}$ and increased to 0.456 at $500 \mathrm{~m}$, then decreased to 0.148 at $1200 \mathrm{~m}$, and increased to 0.286 at $2000 \mathrm{~m}$. However, with DO, the correlation coefficients increased continually from 0.001 at $100 \mathrm{~m}$ to 0.219 at $800 \mathrm{~m}$, but decreased from $800 \mathrm{~m}$ to $1200 \mathrm{~m}$, then increased back to 0.206 at $2000 \mathrm{~m}$. The correlation coefficients between water and $\mathrm{NH}_{3}-\mathrm{N}, \mathrm{BOD}$, and $\mathrm{COD}_{\mathrm{Mn}}$ were similar to $\mathrm{DO}$, but decreased earlier from $300 \mathrm{~m}$ to $1200 \mathrm{~m}$. The correlation coefficients of impervious surface 
with $\mathrm{NH}_{3}-\mathrm{N}, \mathrm{BOD}$, and $\mathrm{COD}_{\mathrm{Mn}}$ decreased from $100 \mathrm{~m}$ to $200 \mathrm{~m}$, but increased continually to $1500 \mathrm{~m}$, then decreased back to $2000 \mathrm{~m}$. However, the correlation coefficient with DO increased continually from 0.244 at $100 \mathrm{~m}$ to 0.365 at $2000 \mathrm{~m}$. The correlation coefficients of crop land with the five water quality variables increased from $100 \mathrm{~m}$ to $2000 \mathrm{~m}$, but the correlation coefficients of forest with the water quality variables changed less than other LULC types.

The results also showed that the main water quality variable affected by LULC type was very different. For example, the correlation coefficient of forest with $\mathrm{DO}$ was higher than other water quality variables, but the correlation coefficient of forest with $\mathrm{COD}_{\mathrm{Cr}}$ was minimal for the water quality variables. The correlation coefficient of water with BOD was higher than other water quality variables, but lower with DO than other water quality variables. The correlation coefficient of crop land with $\mathrm{COD}_{\mathrm{Cr}}$, however, was higher than other water quality variables, but impervious surface had a higher correlation coefficient with $\mathrm{COD}_{\mathrm{Mn}}$.

\subsubsection{Results of Redundancy Analysis}

Redundancy analysis (RDA) showed the correlations of water quality variables and LULC types in the sites along with the different buffer zones (Figure 7). The water chemistry variables were mainly explained by the first two axes, and the first axis explained the variables more than twice as well as the second axis (Table 2). The first axis was positively correlated with forest land and negatively correlated with crop land and impervious surface, which increased in the urban and exurban area. The second axis was positively correlated with crop land and negatively with urbanization. Although the ordination results showed similar interactions to the results of Pearson analyses, the relationship between LULC and the water chemistry variables could be very clearly understood using ordination. From $100 \mathrm{~m}$ to $2000 \mathrm{~m}$, DO was positively correlated with forest, which was the main LULC type in nonurban area sites, $\mathrm{S} 1$ and $\mathrm{S} 2$.

Table 2. Summary of RDA of LULC with respect to the five environmental variables (ENVI) at buffers of $100-2000 \mathrm{~m}$.

\begin{tabular}{|c|c|c|c|c|c|c|c|}
\hline \multirow{3}{*}{ Buffer (m) } & \multicolumn{3}{|c|}{ Axis 1} & \multicolumn{3}{|c|}{ Axis 2} & \multirow{3}{*}{$\begin{array}{c}\text { Total Variance } \\
(\%)\end{array}$} \\
\hline & \multirow{2}{*}{$\begin{array}{l}\text { Correlations of } \\
\text { LULC-ENVI }\end{array}$} & \multicolumn{2}{|c|}{$\%$ Variance of } & \multirow{2}{*}{$\begin{array}{l}\text { Correlations of } \\
\text { LULC-ENVI }\end{array}$} & \multicolumn{2}{|c|}{$\%$ Variance of } & \\
\hline & & LULC & LULC-ENVI & & LULC & LULC-ENVI & \\
\hline 100 & 0.815 & 22.7 & 55.3 & 0.514 & 16.2 & 39.6 & 41.1 \\
\hline 200 & 0.878 & 26.1 & 63.3 & 0.468 & 14 & 34 & 41.2 \\
\hline 300 & 0.895 & 28.8 & 68.1 & 0.452 & 12.6 & 29.9 & 42.3 \\
\hline 400 & 0.892 & 31.6 & 72.3 & 0.445 & 11.7 & 26.7 & 43.7 \\
\hline 500 & 0.891 & 33.7 & 74.9 & 0.442 & 10.9 & 24.4 & 45 \\
\hline 600 & 0.897 & 35.5 & 76.2 & 0.447 & 10.8 & 23.1 & 46.6 \\
\hline 800 & 0.889 & 37.7 & 75.8 & 0.48 & 11.7 & 23.4 & 49.7 \\
\hline 1000 & 0.882 & 38.3 & 75 & 0.503 & 12.6 & 24.5 & 51.1 \\
\hline 1200 & 0.875 & 38.8 & 74.6 & 0.518 & 13 & 24.9 & 52 \\
\hline 1500 & 0.894 & 40.9 & 75.4 & 0.525 & 13.2 & 24.3 & 54.3 \\
\hline 2000 & 0.917 & 41.9 & 78.2 & 0.483 & 11.5 & 21.6 & 53.6 \\
\hline
\end{tabular}





Figure 7. RDA results of LULC and water quality variables within the buffer of $100 \mathrm{~m}, 200 \mathrm{~m}, 300 \mathrm{~m}$, $600 \mathrm{~m}, 800 \mathrm{~m}$, and $2000 \mathrm{~m}$. "imp" means impervious surface.

\subsubsection{Results of Multiple Regression Analysis}

The results of multiple regression analysis indicated that buffer sizes were very important for studying the relationship between LULC types and water quality (Table 3). At buffers of $100 \mathrm{~m}$ and $200 \mathrm{~m}$, forest land was an important factor for water quality over the years. For example, the forest was the first LULC type correlated with the water quality indicators, and it was very significantly negatively correlated with $\mathrm{COD}_{\mathrm{Mn}}$ (Adjust $R^{2}=0.516, p<0.01$ ), $\mathrm{NH}_{3}-\mathrm{N}$ (Adjust $R^{2}=0.629, p<0.01$ ) in 2010, and significantly negatively correlated with $\left.\operatorname{BOD}\left(R^{2}=0.191, p<0.05\right)\right), \operatorname{COD}_{\mathrm{Cr}}\left(R^{2}=0.362\right.$, $p<0.05)$ in 2010, but significantly positively correlated with DO $\left(R^{2}=0.593, p<0.01\right)$ at the $100 \mathrm{~m}$ buffer. However, at the 300-600 m buffers, the mixed types of crop, impervious surface, water, and forest all significantly affected water quality. AT the buffer of $300 \mathrm{~m}$, the $\operatorname{COD}_{\mathrm{Mn}}\left(R^{2}=0.634, p<0.05\right)$, $\operatorname{BOD}\left(R^{2}=0.63, p<0.01\right)$, and $\mathrm{NH}_{3}-\mathrm{N}\left(R^{2}=0.361, p<0.05\right)$ were significantly correlated with water land in 2000; but all of the water quality indicators were significantly correlated with crop land in 2010; and forest land was the first LULC type correlated with the water quality indicators in 2005. From 
$800 \mathrm{~m}$ to $2000 \mathrm{~m}$, however, crop land and impervious surfaces were the main factors affecting water quality. The crop and impervious surfaces were significantly correlated with $\operatorname{COD}_{\mathrm{Mn}}$ (Adjust $R^{2}=$ $0.462, p<0.05$ ), and $\mathrm{NH}_{3}-\mathrm{N}$ (Adjust $R^{2}=0.845, p<0.001$ ) in 2010, and significantly correlated with DO in 2005 (Adjust $R^{2}=0.585, p<0.01$ ) and 2010 (Adjust $R^{2}=0.587, p<0.01$ ).

Table 3. Summary of multiple regression analysis between LULC types in $100 \mathrm{~m}, 300 \mathrm{~m}$, and $2000 \mathrm{~m}$ buffer sizes and water quality variables. We list the three most important LULC variables, based on their standardized coefficients (Std. Coef.).

\begin{tabular}{|c|c|c|c|c|c|c|c|c|}
\hline Buffer (m) & Variables & \multicolumn{2}{|c|}{ First } & \multicolumn{2}{|c|}{ Second } & \multicolumn{2}{|c|}{ Third } & $R^{2} \mathrm{Adj}$ \\
\hline \multirow{10}{*}{100} & $\mathrm{COD}_{\mathrm{Mn} \_} 2000$ & water & 0.516 & forest & -0.406 & $\mathrm{imp}$ & 0.341 & 0.463 \\
\hline & COD $_{\mathrm{Mn} \_2010}$ & forest & $-1.053^{* *}$ & imp & -0.589 & grass & 0.327 & 0.516 \\
\hline & BOD_2000 & water & 0.792 * & $\operatorname{imp}$ & 0.421 & forest & -0.113 & 0.423 \\
\hline & BOD_2005 & forest & -0.529 & $\operatorname{imp}$ & -0.18 & water & -0.134 & -0.055 \\
\hline & $\mathrm{NH}_{3}-\mathrm{N} \_2000$ & water & 0.542 & $\operatorname{imp}$ & 0.338 & forest & -0.213 & 0.187 \\
\hline & $\mathrm{NH}_{3}-\mathrm{N} \_2005$ & forest & -0.657 & $\operatorname{imp}$ & -0.237 & water & -0.097 & 0.101 \\
\hline & $\mathrm{NH}_{3}-\mathrm{N} \_2010$ & forest & $-1.05^{* *}$ & imp & 0.542 & grass & 0.259 & 0.629 \\
\hline & $\mathrm{COD}_{\mathrm{Cr} \_2005}$ & forest & -0.561 & imp & -0.437 & water & -0.162 & -0.022 \\
\hline & COD $_{\mathrm{Cr} \_} 2010$ & forest & $-0.975 *$ & $\operatorname{imp}$ & -0.529 & grass & 0.261 & 0.031 \\
\hline & DO_2005 & forest & $0.777^{*}$ & $\operatorname{imp}$ & 0.214 & water & 0.124 & 0.298 \\
\hline \multirow{11}{*}{300} & 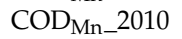 & crop & $0.999 * *$ & imp & 0.672 * & water & 0.181 & 0.552 \\
\hline & BOD_2000 & water & $0.94 * *$ & $\operatorname{imp}$ & 0.418 & forest & -0.071 & 0.63 \\
\hline & BOD_2005 & forest & -0.44 & grass & 0.419 & imp & -0.123 & 0.038 \\
\hline & BOD_2010 & crop & $0.87 *$ & imp & 0.431 & water & 0.102 & 0.285 \\
\hline & $\mathrm{NH}_{3}-\mathrm{N} \_2000$ & water & $0.811^{*}$ & $\operatorname{imp}$ & 0.459 & grass & 0.318 & 0.361 \\
\hline & $\mathrm{NH}_{3}$-N_2005 & forest & -0.563 & grass & 0.499 & imp & -0.158 & 0.347 \\
\hline & $\mathrm{NH}_{3}-\mathrm{N} \_2010$ & crop & $0.942 * *$ & imp & $0.742 * *$ & water & $0.387^{*}$ & 0.7 \\
\hline & $\mathrm{COD}_{\mathrm{Cr} \_} 2005$ & forest & -0.691 & $\operatorname{imp}$ & -0.502 & grass & -0.294 & 0.092 \\
\hline & COD $_{\mathrm{Cr} \_} 2010$ & crop & $0.967 * *$ & imp & $0.707 *$ & water & 0.115 & 0.446 \\
\hline & DO_2005 & forest & 0.844 * & $\operatorname{imp}$ & 0.24 & water & 0.093 & 0.343 \\
\hline & DO_2010 & crop & $-1.025^{* * *}$ & imp & $-0.872 * *$ & grass & -0.254 & 0.751 \\
\hline \multirow{6}{*}{2000} & $\mathrm{NH}_{3}-\mathrm{N} \_2005$ & crop & 0.788 & imp & 0.523 & grass & 0.145 & 0.081 \\
\hline & $\mathrm{NH}_{3}-\mathrm{N} \_2010$ & crop & $1.09 * * *$ & imp & $0.655 * * *$ & grass & $0.45 * *$ & 0.845 \\
\hline & COD $_{\mathrm{Cr} \_} 2005$ & crop & 0.7 & imp & 0.24 & grass & 0.145 & 0.013 \\
\hline & COD ${ }_{\mathrm{Cr} \_} 2010$ & crop & 0.741 & $\operatorname{imp}$ & 0.465 & grass & 0.078 & 0.076 \\
\hline & DO_2005 & crop & $-0.939 * *$ & $i m p$ & $-0.827 * *$ & grass & -0.324 & 0.585 \\
\hline & DO_2010 & crop & $-0.974^{* *}$ & $\operatorname{imp}$ & $-0.798 * *$ & grass & -0.265 & 0.587 \\
\hline
\end{tabular}

* Coefficient is significant at the 0.05 level (two-tailed); ${ }^{* *}$ Coefficient is significant at the 0.01 level (two-tailed);

*** Coefficient is significant at the 0.001 level (two-tailed). "imp" means impervious surface.

\section{Discussion}

Surface water can be polluted by point source pollution (PS) and non-point sources of pollution (NPS) $[7,17]$. With the development of wastewater treatment technology and the increased attention of the government, point source pollution is increasingly controlled in Beijing. For example, the Beijing urban waste treatment rate reached $85 \%$ in 2014 , an increase from the $40 \%$ treatment rate in 2000 [32,42]. However, although PS pollution has been better controlled, the water quality indexed by five variables did not improve significantly, especially in exurban areas (Table 1). Therefore, untreated NPS pollution may continue to be an important factor affecting the water quality in Beijing 
(see also [7]). NPS pollution is considered to be another main factor influencing water quality as well as the PS polluted wastewater without treatment $[43,44]$.

The water quality of Beijing differed greatly according to location (Figure 4), and LULC types correlated well with water chemistry variables (Figures 5 and 6). All of the LULC types, such as impervious surfaces, crop land and forest land, had significant effects on water quality (Table 3). From 2000 to 2010, the area of impervious surface cover increased from $2186 \mathrm{~km}^{2}$ to $2964 \mathrm{~km}^{2}$ in Beijing; the rapid increase of impervious surfaces certainly will impact nearby water quality. The Pearson correlation analyses showed that impervious surface was positively correlated with $\mathrm{NH}_{3}-\mathrm{N}, \mathrm{BOD}$, and $\mathrm{COD}_{\mathrm{Mn}}$ in different buffer zones. Also, with the impervious surface area increasing, the relationship between the impervious surface and water quality become more significant. For example, at the buffer of $100 \mathrm{~m}$, the coefficient of impervious surface and water quality was greater in 2010 than 2000 and 2005. As the proportion of impervious surfaces increased across sites, surface runoff increased with storm water, which is one of the main sources of water pollution in urban areas [12,23,45,46].

The area of agricultural crops was also positively correlated with $\mathrm{COD}_{\mathrm{Mn}}, \mathrm{BOD}$ and $\mathrm{NH}_{3}-\mathrm{N}$, and had the strongest correlation with $\operatorname{COD}_{\mathrm{Cr}}(r>0.5, p<0.05)$. In the exurban site, crop land was the main LULC type. The impact of agricultural non-point source pollution on water quality has received much attention, and many studies report that agricultural activities are strongly correlated with high nutrients in streams, such as nitrogen and phosphorus, along with pesticides [12,20,47]. In the course of agricultural activities, large amounts of organic pesticides and fertilizers are applied to crop land. Most organic pesticides are hard to degrade and residues run into nearby rivers with heavy rain and irrigation. Such contamination could lead to the high COD and concentration of other pollutants in the water [18,48]. In addition, there are many livestock farms in the Beijing exurban area. Due to a shortage of treatment plants, most of the waste directly enters local waterways. In order to protect the water quality in exurban areas, nutrient management, such as nutrient budget, is a mitigation measure to diffuse water pollution from agriculture [49]. Zheng et al. [50] also suggested that payment for ecosystem services (PES) would be an important measure to reduce output from agricultural activities.

The LULC type of water negatively correlated with water quality. Though the waste treatment rate reached $85 \%$ in Beijing by 2014, the untreated waste waters are still a relatively large pollution source. By 2014, water quality of $53.1 \%$ of the rivers in Beijing was poor or very poor [51]. In urban river systems, such as the Beiyun river system, the poor and very poor water quality is more than $80 \%$, while in exurban areas the proportion is nearly $70 \%$. This means the water quality in most urban and exurban river sections is poor, and the reaches upstream of sample stations have no effect on the purification of downstream water. Beijing is characterized by a severe water shortage, and rainfall is the major water source for its rivers. However, rainfall is also a source of pollution in Beijing because of storm runoff. In urban areas, the storm runoff contains a mixture of pollutants from roofs and roads, which feed into the rivers, lakes and wetlands [27,52]. Indeed, lakes and wetlands are the main water source of rivers in dry seasons in the central city area of Beijing. Some researchers believe the LULC type of water should be negatively correlated with water quality parameters because of dilution and purification [27]. However, the water they referred to was reclaimed water from wastewater treatment plants (WWTPs), which has relatively low pollutant concentrations compared with storm runoff water [53].

We found forest land was the only land cover type that is negatively related to pollutants and positively correlated with DO, reflecting its positive role in controlling water quality by filtration, absorption and translation of pollutants before they run into waterways [54-57]. For example, Dosskey et al. [55] reviewed research on how riparian vegetation affected water quality, and found that the vegetation could take up $170 \mathrm{~kg}$ nitrogen and $49 \mathrm{~kg}$ phosphorous per ha every year. Multiple regression analysis demonstrated that forest land in Beijing was the primary factor affecting water quality at a $200 \mathrm{~m}$ buffer. This may be associated with how river management in Beijing is conducted. In order to improve the urban environment, the government constructed green ways on both sides of 10 major rivers and some parks in the center city. By 2017, a projected $1000 \mathrm{~km}$ of green way will be built in 
Beijing, which is believed to benefit people, ecosystems and habitats, and assist in water provision [58]. Bernhardt and Palmer [59] believe that riparian forest is important for maintaining high water quality in stormwater management and stream restoration. Our results suggest that planting forests beside the banks of urban streams will greatly improve the water quality by controlling NPS pollution in Beijing.

Some research has suggested that grass land can also promote water quality $[14,60,61]$, whereas other studies showed that the increasing proportion of grass land was strongly associated with water quality degradation $[19,62]$. Our results, however, showed that the effect of grass land on water quality was sensitive to spatial scale. At buffers of $500 \mathrm{~m}$, the grass land was positively correlated with pollutants of $\mathrm{COD}_{\mathrm{Mn}}, \mathrm{BOD}$, and $\mathrm{NH}_{3}-\mathrm{N}$, but from $600 \mathrm{~m}$ to $2000 \mathrm{~m}$, it was negatively correlated with these pollutants. Planting grass to protect the slope on river banks resulted in intensive management measures, such as watering, fertilizing, spraying insecticide and clipping grass, which would have a negative impact on water quality [27]. However, as the buffer size increases, the planted and highly managed grass land was replaced by minimally managed grass land, which was affected only little by humans. Such lightly managed grass land can intercept some pollutants in rain water that is on its way to rivers [61].

The scale effect was an important factor in the relationship between LULC and water quality but the range remains controversial. For example, Shen et al. [39] found landscape metrics could explain $73 \%$ of the water quality variation at $300 \mathrm{~m}$, but the explanatory power decreased to $64 \%$ at $500 \mathrm{~m}$. Zhou et al. [63] found the LULC pattern had a major impact on water quality in assessing the landscape pattern effects on water quality at scales from $500 \mathrm{~m}$ to $5000 \mathrm{~m}$. Tu [16] explored the relationship between water quality and land use at a regional scale from $20 \mathrm{~km}$ to $80 \mathrm{~km}$ away from the metropolitan Boston area, and showed that land use explained water quality variation across the urbanization gradient in the watersheds. Our results indicated that the forest land was the most important LULC type to affect water quality at $200 \mathrm{~m}$ buffers, but the crop land and impervious surfaces were the primary LULC types effecting water quality at buffers greater than $800 \mathrm{~m}$.

The distribution of wastewater treatment plants (WWTPs) was another important factor in the spatial difference of water quality in Beijing. Our results showed that the pollutant concentrations were very high at the urban sampling stations, but the concentration of pollutants at the exurban station was higher than in the urban area (Table 1). The results demonstrated that the exurban river water quality was worse than that in the urban area, and the public and the government should pay more attention to the exurban river environment. For example, there should be more monitoring stations and more WWTPs in the exurban area. By 2010, there was a total of 60 WWTPs in Beijing, and nearly 80 percent of them are in urban areas. There are only 16 WWTPs capable of processing more than 50,000 tons per day and 13 of them are distributed in the urban area; the other three WWTPs are scattered in different areas. Pinggu district, for example, the most important producer of agricultural and subsidiary products in Beijing, has only three WWTPs and just one plant with a processing capacity of about 80,000 tons per day. The other two WWTPs in Pinggu have processing capacities of only 1500 tons per day. Most untreated wastewater is discharged into rivers and degrades the water quality. Lack of WWTPs and the shortage in processing capacity in the exurban and rural areas are a big problem faced by most cities in China $[20,64]$. Therefore, it is important to build WWTPs in exurban and rural areas to improve the water quality and people's living environment.

\section{Conclusions}

We analyzed the spatial and temporal patterns of water quality in Beijing. Our results showed that water quality was significantly different in areas exhibiting different degrees of urbanization, and that LULC was an important factor in determining water quality. In addition we documented that forest areas have a positive relationship with water quality. In contrast, other LULC types, such as impervious surfaces, crops, and water, were negatively related with water quality. The grass land, however, had differing effects on water quality because of different intensities of grass land management at wider buffers. The grass land near rivers was mainly used to protect the slope, and it may have negative 
impacts on water quality as a result of intensive management. However, as the buffer size increases, the managed grass land near the river bank is replaced by the natural grass land, which may have a positive effect on water quality by retaining pollutants from storm water. Accordingly, we believe that less fertilizing and spraying of insecticide, decreasing artificial grass land, and keeping the grass land in a more natural state are better strategies than intensive management within buffer zone to ensure water quality.

Our results also showed that buffer size was an important factor affecting water quality. Within the $200 \mathrm{~m}$ buffer zone, forest land was the most important LULC type affecting water quality, and it was positively correlated with water quality. However, forest, crop, and water were the most important types affecting water quality from $300 \mathrm{~m}$ to $800 \mathrm{~m}$. As the buffer zone increased to $800 \mathrm{~m}$, crop land and impervious surfaces gradually became the main LULC types affecting water quality, and they were negatively correlated with water quality. Finally, we suggest increasing the proportion of forest land in the buffer zones with minimally managed grass land near the river in urban areas, and maintaining the natural characteristics in nonurban areas as well as preventing the development of the river bank in exurban areas may all be important for controlling NPS pollution.

Acknowledgments: We are grateful to Beijing Municipal Environmental Monitoring Center for hydrologic monitoring stations information and water quality data, as well as Wenjuan Yu and Chunmeng Han for help with the site mapping. We also thank to Daniel L. Childers for constructive suggestions on the manuscript. Funding for this study was supported by the One Hundred Talents Program of Chinese Academy of Science and the National Natural Science Foundation of China (Grant No. 41371197 and 41422104).

Author Contributions: Xiang Chen and Weiqi Zhou conceived and designed the research; Xiang Chen and Weiqi Zhou performed the research; Xiang Chen analyzed the data; and Xiang Chen, Weiqi Zhou, Steward T. A. Pickett, Weifeng Li and Lijian Han wrote the paper.

Conflicts of Interest: The authors declare no conflict of interest.

\section{References}

1. Vitousek, P.M.; Mooney, H.A.; Lubchenco, J.; Melillo, J.M. Human Domination of earth's ecosystems. Science 1997, 277, 494-499. [CrossRef]

2. Grimm, N.B.; Grove, J.M.; Pickett, S.T.A.; Redman, C.L. Integrated approaches to long-term studies of urban ecological systems. Bioscience 2000, 50, 571-584. [CrossRef]

3. Pickett, S.T.A.; Cadenasso, M.L.; Grove, J.M.; Boone, C.G.; Groffman, P.M.; Irwin, E.; Kaushal, S.S.; Marshall, V.; McGrath, B.P.; Nilon, C.H.; et al. Urban ecological systems: Scientific foundations and a decade of progress. J. Environ. Manag. 2011, 92, 331-362. [CrossRef] [PubMed]

4. Paul, M.J.; Meyer, J.L. Streams in the urban landscape. Annu. Rev. Ecol. Syst. 2001, 32, 333-365. [CrossRef]

5. Walsh, C.J.; Roy, A.H.; Feminella, J.W.; Cottingham, P.D.; Groffman, P.M.; Morgan, R.P., II. The urban stream syndrome: Current knowledge and the search for a cure. J. N. Am. Benthol. Soc. 2005, 24, 706-723. [CrossRef]

6. Grimm, N.B.; Faeth, S.H.; Golubiewski, N.E.; Redman, C.L.; Wu, J.; Bai, X.; Briggs, J.M. Global change and the ecology of cities. Science 2008, 319, 756-760. [CrossRef] [PubMed]

7. Shen, Z.; Hou, X.; Li, W.; Aini, G. Relating landscape characteristics to non-point source pollution in a typical urbanized watershed in the municipality of Beijing. Landsc. Urban Plan. 2014, 123, 96-107. [CrossRef]

8. King, R.S.; Baker, M.E.; Whigham, D.F.; Weller, D.E.; Jordan, T.E.; Kazyak, P.F.; Hurd, M.K. Spatial considerations for linking watershed land cover to ecological indicators in streams. Ecol. Appl. 2005, 15, 137-153. [CrossRef]

9. Kang, J.H.; Lee, S.W.; Cho, K.H.; Ki, S.J; Cha, S.M.; Kim, J.H. Linking land-use type and stream water quality using spatial data of fecal indicator bacteria and heavy metals in the Yeongsan River Basin. Water Res. 2010, 44, 4143-4157. [CrossRef] [PubMed]

10. Pacheco, F.A.L.; Sanches Fernandes, L.F. Environmental land use conflicts in catchments: A major cause of amplified nitrate in river water. Sci. Total Environ. 2016, 548-549, 173-188. [CrossRef] [PubMed]

11. Valle Junior, R.F; Varandas, S.G.P.; Sanches Fernandes, L.F.; Pacheco, F.A.L. Groundwater quality in rural watersheds with environmental land use conflicts. Sci. Total Environ. 2014, 493, 812-827. [CrossRef] [PubMed] 
12. Karr, J.R.; Schlosser, I.J. Water resources and the land-water interface. Science 1978, 201, 229-234. [CrossRef] [PubMed]

13. Osborne, L.L.; Wiley, M.J. Empirical relationships between land-use cover and stream water-quality in an agricultural watershed. J. Environ. Manag. 1988, 26, 9-27.

14. Sliva, L.; Williams, D.D. Buffer zone versus whole catchment approaches to studying land use impact on river water quality. Water Res. 2001, 35, 3462-3472. [CrossRef]

15. Zampella, R.A.; Procopio, N.A.; Lathrop, R.G.; Dow, C.L. Relationship of land-use/land-cover patterns and surface-water quality in the Mullica River Basin. J. Am. Water. Resour. Assoc. 2007, 43, 594-604. [CrossRef]

16. Tu, J. Spatially varying relationships between land use and water quality across an urbanization gradient explored by geographically weighted regression. Appl. Geogr. 2011, 31, 376-392. [CrossRef]

17. Carpenter, S.R.; Caraco, N.F.; Correll, D.L.; Howarth, R.W.; Sharpley, A.N.; Smith, V.H. Nonpoint pollution of surface waters with phosphorus and nitrogen. Ecol. Appl. 1998, 8, 559-568. [CrossRef]

18. Kolpin, D.W.; Furlong, E.T.; Meyer, M.T.; Thurman, E.M.; Zaugg, S.D.; Barber, L.B.; Buxton, H.T. Pharmaceuticals, hormones, and other organic wastewater contaminants in U.S. streams, 1999-2000: A national reconnaissance. Environ. Sci. Technol. 2002, 36, 1202-1211. [CrossRef] [PubMed]

19. Ahearn, D.S.; Sheibley, R.W.; Dahlgren, R.A.; Anderson, M.; Johnson, J.; Tate, K.W. Land use and land cover influence on water quality in the last free-flowing river draining the western Sierra Nevada, California. J. Hydrol. 2005, 313, 234-247. [CrossRef]

20. Ongley, E.D.; Zhang, X.; Tao, Y. Current status of agricultural and rural non-point source pollution assessment in China. Environ. Pollut. 2010, 158, 1159-1168. [CrossRef] [PubMed]

21. Pacheco, F.A.L.; Santos, R.M.B.; Sanches Fernandes, L.F.; Pereira, M.G.; Cortes, R.M.V. Controls and forecasts of nitrate fluxes in forested watersheds: A view over mainland Portugal. Sci. Total Environ. 2015, 537, 421-440. [CrossRef] [PubMed]

22. Santos, R.M.B.; Sanches Fernandes, L.F.; Pereira, M.G.; Cortes, R.M.V.; Pacheco, F.A.L. A framework model for investigating the export of phosphorus to surface waters in forested watersheds: Implications to management. Sci. Total Environ. 2015, 536, 295-305. [CrossRef] [PubMed]

23. Arnold, C.L.; Gibbons, C.J. Impervious surface coverage: The emergence of a key environmental indicator. J. Am. Plan. Assoc. 1996, 62, 243-258. [CrossRef]

24. Sonoda, K.S.; Yeakley, J.A.; Walker, C.J. Near-stream landuse effects on streamwater nutrient distribution in an urbanizing watershed. J. Am. Water Resour. Assoc. 2001, 37, 1517-1532. [CrossRef]

25. Wang, J.; Da, L.; Song, K.; Li., B. Temporal variations of surface water quality in urban, exurban and rural areas during rapid urbanization in Shanghai, China. Environ. Pollut. 2008, 152, 387-393. [CrossRef] [PubMed]

26. Li, W.; Shen, Z.; Tian, T.; Liu, R.; Qiu, J. Temporal variation of heavy metal pollution in urban stormwater runoff. Front. Environ. Sci. Eng. 2012, 6, 692-700. [CrossRef]

27. Gilbert, J.K.; Clausen, J.C. Stormwater runoff quality and quantity from asphalt, paver, and crushed stone driveways in Connecticut. Water Res. 2006, 40, 826-832. [CrossRef] [PubMed]

28. Borin, M.; Vianello, M.; Morari, F.; Zanin, G. Effectiveness of buffer strips in removing pollutants in runoff from a cultivated field in North-East Italy. Agric. Ecosyst. Environ. 2005, 105, 101-114. [CrossRef]

29. Sweeney, B.W.; Newbold, J.D. Streamside forest buffer width needed to protect stream water quality, habitat, and organisms: A literature review. J. Am. Water. Resour. Assoc. 2014, 50, 560-584. [CrossRef]

30. Houlahan, J.E.; Findlay, C.S. Estimating the 'critical' distance at which adjacent land-use degrades wetland water and sediment quality. Landsc. Ecol. 2004, 19, 677-690. [CrossRef]

31. Vörösmarty, C.J.; McIntyre, P.B.; Gessner, M.O.; Dudgeon, D.; Prusevich, A.; Green, P.; Glidden, S.; Bunn, S.E.; Sullivan, C.A.; Liermann, C.R.; et al. Global threats to human water security and river biodiversity. Nature 2010, 467, 555-561. [CrossRef] [PubMed]

32. Beijing Municipal Bureau of Statistics. Statistical Communique on the 2014 National Economic and Social Development of the City of Beijing. Available online: http://www.bjstats.gov.cn/ xwgb/tjgb/ndgb/ 201502/t20150211_288370.htm (accessed on 25 November 2015).

33. Chinese State Environment Protection Bureau. Water and Wastewater Monitoring Analysis Methods, 4th ed.; Chinese Environment Science Press: Beijing, China, 2002.

34. Chander, G.; Markham, B.L.; Helder, D.L. Summary of current radiometric calibration coefficients for Landsat MSS, TM, ETM+, and EO-1 ALI sensors. Remote Sens. Environ. 2009, 113, 893-903. [CrossRef] 
35. Zhou, W.; Troy, A. An object-oriented approach for analysing and characterizing urban landscape at the parcel level. Int. J. Remote Sens. 2008, 29, 3119-3135. [CrossRef]

36. Zhou, W.; Troy, A.; Grove, M. Object-based land cover classification and change analysis in the Baltimore Metropolitan Area using multitemporal high resolution remote sensing data. Sensors 2008, 8, 1613-1636. [CrossRef]

37. Yu, W.; Zhou, W.; Qian, Y.; Yan, J. A new approach for land cover classification and change analysis: Integrating backdating and an object-based method. Remote Sens. Environ. 2016, 177, 37-47. [CrossRef]

38. Qian, Y.; Zhou, W.; Yu, W.; Pickett, S.T.A. Quantifying spatiotemporal pattern of urban greenspace: New insights from high resolution data. Landsc. Ecol. 2015, 30, 1165-1173. [CrossRef]

39. Shen, Z.; Hou, X.; Li, W.; Aini, G.; Chen, L.; Gong, Y. Impact of landscape pattern at multiple spatial scales on water quality: A case study in a typical urbanized watershed in China. Ecol. Indic. 2015, 48, 417-427. [CrossRef]

40. Ministry of Environmental Protection of China. Technical Guideline for Delineating Source Water Protection Areas; China Environmental Science Press: Beijing, China, 2007; p. 3.

41. Ter Braak, C.J.F.; Smilauer, P. CANOCO Reference Manual and CanoDraw for Windows User's Guide: Software for Canonical Community Ordination (Version 4.5); Microcomputer Power: Ithaca, NY, USA, 2002.

42. Beijing Municipal Bureau of Statistics. Statistical Communique on the 2000 National Economic and Social Development of the City of Beijing. Available online: http://www.bjstats.gov.cn/xwgb/tjgb/ ndgb/200605/t20060526_42168.htm (accessed on 25 November 2015).

43. Tsihrintzis, V.A.; Hamid, R. Modeling and management of urban stromwater runoff quality: A review. Water Resour. Manag. 1997, 11, 137-164.

44. Tang, Z.; Engel, B.A.; Pijanowski, B.C.; Lim, K.J. Forecasting land use change and its environmental impact at a watershed scale. J. Environ. Manag. 2005, 76, 35-45. [CrossRef] [PubMed]

45. Schueler, T.R.; Fraley-McNeal, L.; Cappiella, K. Is impervious cover still important? Review of recent research. J. Hydrol. Eng. 2009, 14, 309-315. [CrossRef]

46. Hopkins, K.G.; Morse, N.B.; Bain, D.J.; Bettez, N.D.; Grimm, N.B.; Morse, J.L.; Palta, M.M.; Shuster, W.D.; Bratt, A.R.; Suchy, A.K. Assessment of regional variation in streamflow responses to urbanization and the persistence of physiography. Environ. Sci. Technol. 2015, 49, 2724-2732. [CrossRef] [PubMed]

47. Freeman, M.C.; Pringle, C.M.; Jackson, C.R. Hydrologic connectivity and the contribution of stream headwaters to ecological integrity at regional scales. J. Am. Water Resour. Assoc. 2007, 43, 5-14. [CrossRef]

48. Wauchope, R.D. The pesticide content of surface water draining from agricultural fields-a review. J. Environ. Qual. 1978, 7, 459-472. [CrossRef]

49. Shober, A.L.; Hochmuth, G.; Wiese, C. An Overview of Nutrient Budgets for Use in Nutrient Management Planning; Institute of Food and Agricultural Sciences: Gainesville, FL, USA, 2011; Available online: http:/ / edis.ifas.ufl.edu (accessed on 26 April 2016).

50. Zheng, H.; Robinson, B.E.; Liang, Y.C.; Polasky, S.; Ma, D.C.; Wang, F.C.; Ruckelshaus, M.; Ouyang, Z.Y.; Daily, G.C. Benefits, costs, and livelihood implications of a regional payment for ecosystem service program. Proc. Natl. Acad. Sci. USA 2013, 110, 16681-16686. [CrossRef] [PubMed]

51. Beijing Municipal Environmental Protection Bureau. Beijing Environmental Statement 2014; Beijing Municipal Environmental Protection Bureau: Beijing, China, 2014.

52. Lee, J.H.; Bang, K.W. Characterization of urban stormwater runoff. Water Res. 2000, 34, 1773-1780. [CrossRef]

53. Yi, L.; Jiao, W.; Chen, X.; Chen, W. An overview of reclaimed water reuse in China. J. Environ. Sci. 2011, 23, 1585-1593. [CrossRef]

54. Burton, M.L.; Samuelson, L.J.; Pan, S. Riparian woody plant diversity and forest structure along an urban-rural gradient. Urban Ecosyst. 2005, 8, 93-106. [CrossRef]

55. Dosskey, M.G.; Vidon, P.; Gurwick, N.P.; Allan, C.J.; Duval, T.P.; Lowrance, R. The role of riparian vegetation in protecting and improving chemical water quality in streams. J. Am. Water Resour. Assoc. 2010, 46, 261-277. [CrossRef]

56. Roberts, W.M.; Stutter, M.I.; Haygarth, P.M. Phosphorus retention and remobilization in vegetated buffer strips: A review. J. Environ. Qual. 2012, 41, 389-399. [CrossRef] [PubMed]

57. Li, Y.; Chen, Z.; Lou, H.; Wang, D.; Deng, H.; Wang, C. Denitrification controls in urban riparian soils: Implications for reducing urban nonpoint source nitrogen pollution. Environ. Sci. Pollut. Res. 2014, 21, 10174-10185. [CrossRef] [PubMed] 
58. Palmer, M.A.; Liu, J.; Matthews, J.H.; Mumba, M.; D'Odorico, P. Manage water in a green way. Science 2015, 349, 584-585. [CrossRef] [PubMed]

59. Bernhardt, E.S.; Palmer, M.A. Restoring streams in an urbanizing world. Freshw. Biol. 2007, 52, 738-751. [CrossRef]

60. Osborne, L.L.; Kovacic, D.A. Riparian vegetated buffer strips in water-quality restoration and stream management. Freshw. Boil. 1993, 29, 243-258. [CrossRef]

61. Ouyang, W.; Skidmore, A.K.; Toxopeus, A.G.; Hao, F. Long-term vegetation landscape pattern with non-point source nutrient pollution in upper stream of Yellow River basin. J. Hydrol. 2010, 389, 373-380. [CrossRef]

62. Xiao, H.; Ji, W. Relating landscape characteristics to non-point source pollution in mine waste-located watersheds using geospatial techniques. J. Environ. Manag. 2007, 82, 111-119. [CrossRef] [PubMed]

63. Zhou, T.; Wu, J.; Peng, S. Assessing the effects of landscape pattern on river water quality at multiple scales: A case study of the Dongjiang River Watershed, China. Ecol. Indic. 2012, 23, 166-175. [CrossRef]

64. Wang, M.; Webber, M.; Finlayson, B.; Barnett, J. Rural industries and water pollution in China. J. Environ. Manag. 2008, 86, 648-659. [CrossRef] [PubMed]

(C) 2016 by the authors; licensee MDPI, Basel, Switzerland. This article is an open access article distributed under the terms and conditions of the Creative Commons Attribution (CC-BY) license (http://creativecommons.org/licenses/by/4.0/). 